Review

\title{
The Rainfall Factor of Climate Change Effects on the Agricultural Environment: A Review
}

\author{
Olumuyiwa Idowu Ojo and Masengo Francois Ilunga \\ Department of Civil and Chemical Engineering, University of South Africa, Florida Campus, South Africa
}

\author{
Article history \\ Received: 13-05-2017 \\ Revised: 11-09-2017 \\ Accepted: 19-10-2017 \\ Corresponding Author: \\ Olumuyiwa Idowu Ojo \\ Department of Civil and \\ Chemical Engineering, \\ University of South Africa, \\ Florida Campus, South Africa \\ E-mail: ojooi@unisa.ac.za
}

\begin{abstract}
The study of the climatic elements is vital for sustainable development of agriculture of a region. Particularly, rainfall temporal analyses for trends, fluctuations and periodicities are necessary as such can indirectly furnish the status of an environment. A trend may be quite instructive for different segments of the human and natural systems. Extreme weather events that can lead to events such as drought, prolonged heat spell and flooding while these can be accessed through the statistical analysis of a region's temporal rainfall regime. The global concern on the apparent deterioration in all of the earth's natural systems, particularly the climate sub-system and global warming with climate change pandemic renders credence to trend and periodicity analyses of climatic elements. This paper therefore did a review of studies of cases of climate change effects on the agricultural environment with emphasis on rainfall, as an important factor.
\end{abstract}

Keywords: Climate Change, Rainfall Factor, Agriculture, Environment

\section{Introduction}

Climate change resulting from human activities such as increase in the concentration of Greenhouse Gases (GHGs) in the atmosphere and food insecurity are two closely connected perils facing humanity in the $21 \mathrm{st}$ century. Climate change due to anthropogenic factors has shown that the globe is warming (Odingo, 2008; IPCC, 2007). Numerous scientific accounts on global warming have indicated that the average global temperature has increased by around $0.7^{\circ} \mathrm{C}$ since the advent of the industrial revolution (Asafu-Adjaye, 2008). The trend, as shown by different study, is accelerating such that the average temperature is rising at $0.2^{\circ} \mathrm{C}$ every decade (Ofori-Boateng, 2012). With the increasing level in the world's temperature, rainfall patterns are changing locally, ecological zones are shifting, the seas are warming and Ice Caps are melting (IPCC, 2007). Developing countries, African countries exclusively, have been termed to be at danger as the tropical regions stand to experience some of the most serious effects from climate change and agriculture, which takes an important part of employment and food provision in Africa, is highly susceptible to climate variability. UNFCCC global discussion forum reported that the rising global temperature is likely to boost agricultural production in the temperate regions and expected to reduce yields in the tropical areas of the world (WTOUNEP, 2009). The report further observed that the increase in average temperature between 1980/1999 and $2080 / 2099$ would be in the range of $3-4^{\circ} \mathrm{C}$ across the entire African continent which is 1.5 times higher the global level. The United Nations Environmental Programme (UNEP) defined climate change as harsh reactions of the weather phenomenon which creates negative effects on agriculture, water resources, human health, vegetation, soil, depletion of ozone layer and doubling of carbon dioxide in the ecosphere (Ezra, 2010). Climate change has the tendency of affecting all natural and human systems and maybe a threat to human development and survival socially, politically and economically (Ali, 2011). Most of the dryness that occur in arid and semi-arid regions have been found to be related with a late start of the rainy season and early stopping of the rains, resulting in extreme reductions of the length of the rainy season.

\section{Drought as a Climate Change Variable}

Drought is a condition of wide but short-term climatic variation, which results in inadequate rainfall to meet the socio-economic demands of an area in terms of water supply for domestic and industrial uses, agriculture and ecosystem. One of the earliest and most influential interpretations of the cause of drought in the Sahel was that reported by Charney et al. (1977), which suggested that reductions in rainfall were the result of human activity. Drought in Sahara desert region is often 
attributed to a southward displacement of the InterTropical Convergence Zone (ITCZ), but this explanation has been rejected because it failed to explain many important characteristics of rainfall such as late onset or early stoppage (Nicholson and Tucker, 1998; Nicholson, 1993). Other studies have suggested that the build-up in atmospheric dust, aggravated by anthropogenic factors such as usage of fire-wood, bush burning and poor farming practices, as well as, frequent sand storms, which cause changes in surface reflective power may be responsible for extreme climatic changes in the Sahel (Ekpoh, 2007). However, modification of the African Monsoon by regional and global-scale patterns of seasurface temperature provides the best explanation for variations in Sahelian rainfall on multi-year to decadal time-scales. Relationships between sea- surface temperature patterns and Sahelian rainfall are well established from statistically based climatological analyses and have been used with some success in seasonal rainfall forecasts in the region (Folland et al., 1986; Ward et al., 1993). According to Ekpoh (1991; Akonga, 2001) the Sahelian drought has been shown to have tele-connections with El Nino Southern Oscillation (ENSO), a phenomenon that is associated with periodic fluctuation in the intensity of the inter-tropical atmospheric and oceanic circulations that is usually coincident with an anomalous warming of the Eastern Tropical Pacific Ocean. Study by Giannini et al. (2003) further identified sea-surface temperature as the principal driver of Sahelian rainfall variability, which they modeled successfully for the period 1930-2000 using a model that also represent the land-atmosphere interaction, through moisture feedbacks. Similar studies that have similarly used long-term data from a number of synoptic stations in Nigeria also yielded some very useful information on the recurrence, persistence and periodicity of severe droughts in Nigeria (Adefolalu, 1986; Tarhule and Woo, 1998).

\section{Precipitation as a Climate Change Variable}

Agro-meteorology is the study of the effect of various climate factors on agriculture. Climatic variable has direct influence on agricultural production and are being used as basis for forecasting agricultural production. Changes in climate can be monitored through changes in the atmospheric temperature and through rainfall fluctuations. Climate change especially with respect to rainfall fluctuation with time has raised public interest because of the disruption in the socioeconomic system brought about by drought or floods (Fasheun et al., 1995). The effect of climate change is manifest in the quantity of surface water in the valley, the size of ground water recharge: on the socio-economic side. Climate variability can incur limited impact on the provision of electricity (for heating, cooling, irrigation and lighting), the coasts of ranching and farming, the incidence of certain diseases vector (Valley fever), floodwater destruction and reductions in tourism and business. Timothy et al. (2002) stated that on a long term, climate variability might affect the availability of ground and surface water supplies however, further research is needed to establish the nature of this constraint. Precipitation, an important element of the hydrological cycle is highly valuable, both spatially and temporally at different scales (inter-annual and intraannual). Change in high precipitation, based on these indices, has been analyzed for individual European countries and stations and, to a lesser extent, for Europe as a whole. Klein-Tank and Konnen (2003) found that all European-average wet extremes increased during the second half of the 20th century (1946-1999), although low spatial coherence was found in the trend, there is also evidence of unsuitable large changes in extremes compared to annual totals. Studies by Zolina, (2005; Moberg et al., 2006) found that at the station where the annual precipitation amount has increased, the index for the fraction of the annual precipitation are due to very wet days shows disproportionately large changes in precipitation extremes. Also at areas with a reduction in annual precipitation amount, there is no pronounced response of the extremes. Centennial (1901-2000) trends in precipitation extremes for Europe show regional differences in seasonality (Zolina, et al 2005; Moberg et al., 2006). The most significant feature of central and western European precipitation is the significant increase in winter precipitation, in both the mean precipitation intensity and moderately strong events. There is a little evidence of significant change in the precipitation indices for summer (Moberg and Jones, 2005). An analysis carried out by Osborn et al. (2000) for the United Kingdom, which was based on a dense data network during the second half of 20th century, detected a tendency towards wetter conditions in winter and drier conditions in summer. During the same period in western Germany, the extreme heavy precipitation in winter and transition seasons has also become extreme, in terms of size and frequency. However, in contrast to winter, the summer trend in extreme heavy precipitation is towards less extreme (Hundecha and Bardossy, 2005). Tosic and Unkasevic (2005) attributed rainfall as the greatest contribution to the inflow and the more it occurs, the greater the tendency for runoff which in some cases result to flood occurrence.

The variations in rainfall can be seen as response of the climate system either to external forcing or to fedback processes. Ajayi (1998) also added that rainfall is the most important single meteorological parameter, which conditions agriculture because; it provides the water necessary for the functioning of the soil-plantatmosphere system. Rainfall varied widely while other parameters are rather conservative in time and space. Rainfall is characterized by a multiple, non-symmetric 
cycle of irregularities with varying sizes; these observations confirm earlier findings by Bunting et al. (1976). However, Winstanley (2003) has pointed out that the climatic zones in the northern hemisphere slowly shifted northward for about a century until around 1930 . Since then, there has been southward movement and therefore reduced rainfall in the Sudano-Sahelian region of West Africa. In addition, outcomes of rainfall studies in any region can help the decision makers to manage their water resources, agricultural, environmental and other projects related to water. Morele et al. (2003) performed a spectral analysis of the time series corresponding to the main monthly precipitation regimes of the Ibereian Peninsula and showed that weekly, monthly and annual rainfall are very important in Agricultural project, water project and environmental projection. While rainfall variability is a major characteristic of the Sahelian climate, since 1969 there have dramatic reductions in mean annual rainfall throughout the region (Le Barbe and Lebel, 1997; Ekpoh, 1999; Hulme, 2001; Dai et al., 2004). According to IPCC (2001), a rainfall decrease of $29-49 \%$ has been observed in the 1968-1997 period compared to the 19311960 baseline period within the Sahel region. Rainfall variability analysis at a time scale from year to days is as much a characteristic of climate as a total amount recorded.

\section{Rainfall Analysis}

Rainfall is a very important input to the design involving water resources engineering and other environmental related project. Rainfall analyses are carried out for the prediction of extreme amount and repetition of floods and in the design of irrigation and drainage requirements (Ekwue et al., 1997). Rainfall analysis can be undertaken at different time scales such as hourly, daily, weekly, monthly or seasonally. Rainfall analysis performed by Adefolalu (2007) indicated that both the amount and area of the secondary rainfall maximum at $1010 \mathrm{~N}$ latitude in Nigeria has declined with time and at the same time, the belt of relative minimum rainfall appears to be expanding temporally. This decrease in the dry season contribution to annual rainfall suggests a drier environment in the long-term. Tarhule and Woo (1998) have also used climatic records to examine recent changes in several rainfall characteristics of Northern Nigeria. Their study used the Pettitt and the Mann-Kendall tests to analyze sudden changes and trends in the rainfall data. The results confirmed sudden changes in the time series of annual rainfall and a notable reduction in the number of rain days, especially for locations north of latitude $11 \mathrm{oN}$. In another study by Ekpoh (2007) for station analysis using long-term rainfall data from Katsina, Zaria and Kano in Nigeria to test for trend using the 5-year moving average, he found a decrease in annual rainfall in the three areas between 1969 and 1999. Tarhule and Woo
(1998) worked on the changes in rainfall characteristics in Northern Nigeria; they concluded that the important statistical trends in rainfall were found occurring in Northern Nigeria in the period after the change point, amounting to between -1 and $-3 \mathrm{~mm} /$ year. This may explain why agricultural activities continued throughout the region despite the severe reduction of annual rainfall. Similarly, Hess et al. (1995) analyzed rainfall trend in North East of the Arid Zone of Nigeria using 1961-1990 record of Nguru, Potikun and Maiduguri. They concluded that there was a consistent decrease of 8 $\mathrm{mm} /$ year in annual rainfall in all the areas. Their observation was that the majority of the reduction occurred in August or September and that the main reason for the decrease was the reduction of 6.25 days in number of rain days observed during the rainy season. A study by Ajayi (1998) on Agro statistical analysis of rainfall data for the humid and sub-humid zones of Nigeria showed that there is a need to cultivate early maturing plant as it is clear that the growing season is reducing in length over the years. He concluded that there was a reduction in the number of rainy days while the monthly mean temperature increased and there were variations in the rainfall distribution on annual, monthly and daily basis. Studies in some parts of Africa have shown that some parts have been dried the last few decades (Nicholson et al., 2002; L'Hôte et al., 2002). Analysis of rainfall and runoff record from the southwestern part of Ghana showed that there is a significant reduction in rainfall and runoff in the region, which have been linked to the influence of climate change (Opoku-Ankomah and Amisigo, 1998). Brazdil (1992) described the fluctuations of precipitation in Europe using the series of annual areal precipitation sums. A general view on the seasonal behavior in precipitation trend in different European countries during 1961-1990 and 1891-1990 were investigated by Schonwiese et al. (1994; Schonwiese and Rapp, 1997). Thus, analysis of rainfall on daily basis is useful especially for agricultural purposes as stated in the studies by Sivakumar (1992).

\section{The Effects of Climate Change on Agricultural Environments}

Agriculture is one of the most sensitive systems to climate change since meteorological variables determine resource availability and control fundamental processes involved crop growth and development. Studies show a variety of examples where researchers have addressed the effects of climate variability on crops (Rubas et al., 2006) as well as the impacts of climate change on crop yields (Parry et al., 2004). Agriculture in developing countries must undergo a significant transformation in order to meet related challenges of achieving food security and responding to climate change. Most estimates indicate that climate change is likely to reduce agricultural production, production stability and incomes 
in some areas that already have high levels of food insecurity. Therefore, developing Climate-Smart Agriculture is very important to achieving future food security and climate change goals (FAO, 2010). In the study by Ziervogel et al. (2008), the variability of the climate has been a serious issue in a sustainable environment as the crop yield and production is very important to the economy and livelihood of the people of Africa and the world at large. Climate change could have both positive and negative impacts and these could be measured in terms of effects on crop growth, availability of soil water, soil fertility and erosion, incidents of pests and diseases and sea level rise. According to IPCC's projections (2002), for the tropic humid zones precipitation increases of about 2-3\% for each degree of global warming may be expected (IPCC, 2002). Thus, it is reasonable to expect that the precipitation would probably increase by approximately $5-20 \%$ in the very humid areas of the forest regions and southern savanna areas. The increase in temperature in these areas would also possibly increase evaporation, thereby reducing the increase in precipitation. According to Salami (2010), rainfall in the very humid regions is expected to increase and may be accomplished by increase in cloudiness and rainfall intensity, particularly during severe storms. It could also result in shifts in geographical patterns of precipitation and changes in the sustainability of the environment and management of resources.

\section{The Effects of Change on Soil Conditions}

Climate change results in increased temperature, changing precipitation patterns, floods and droughts. These events affect us and as well affect how soil responds to the events. Soil is a part of the natural world that is both affected by and contributing to global warming. Soil is the one of the largest sources of carbon in the world. It is primarily accumulated through plants, the soil then directly absorbs the carbon as the plants decay. Additionally, microbes in the soil break down dead leaves and animals and carbon is accumulated. Carbon in the soil is broken down naturally and released into the atmosphere as carbon dioxide gas. According to Field et al. (2007), such conditions that are widespread throughout the warmer and drier regions of southern Europe will be aggravated by temperature rise coupled with reduced rainfall. Climate change is expected to have an impact on soil (EEA, 2009; EEA-JRC-WHO, 2008). Climate change will affect directly and, through land-use change, indirectly on a wide range of soil processes and properties that will determine the future ability of land to fulfill primary functions that are important for all terrestrial ecosystems, as well as several socioeconomic activities, that support the well-being of society. Climate change can be expected to modify soil structure through the physical processes of shrink-swell and freeze-thaw, as well as through changes in soil organic matter contents. Disturbance regimes are changing drastically under the combined effect of global change, biological invasions and direct human modification of the environment while rainfall patterns are also changing, with some regions becoming drier and others becoming wetter and more vulnerable to flooding (Asit and Neenu, 2012).

\section{The Effects of Change on Crop Production}

IPCC predicted that climate change may increase the frequency and severity of weather extremes, such as extreme precipitation, tropical cyclones and heat waves in certain regions. The effects of climate change on other small-scale extreme weather phenomena, such as lightening and hailstorms, remain uncertain (IPCC, 2007). According to Mills (2007), the tendency of global warming to increase the vulnerability to weather extremes is especially relevant for the insurance sector. Savanna and semi-arid areas suffer from seasonal and inter annual climatic variability and there have been droughts and effective desertification processes. This situation may have declined by the expected decrease in rainfall with greater drought probabilities and more rainfall variabilities and unreliabilities. As stated by Mustapha and Adzemi 2014, these events would have negative impacts on agricultural production and changes in the pattern of rainfall will possibly lead to drought and/or flooding. Increase in population and food consumption patterns indicate that agricultural production will need to increase by $70 \%$ by 2050 to meet global demand for food. The effects of climate change will reduce productivity and lead to greater instability in production in agricultural sector (crop and livestock, fisheries and forestry) in communities that already have high levels of food insecurity and environmental degradation and limited option for coping with extreme weather conditions (Reuben, 2012). In many areas of the world where agricultural productivity is already low and the means of coping with adverse events is limited, climate change is expected to reduce productivity to even lower levels and make production more unstable (Stern, 2006; Cline, 2007; Fisher et al., 2007). Under such extreme climate conditions, prolonged changes in the patterns of temperature and precipitation are expected to shift production seasons, pest and disease patterns and modify the set of feasible crops affecting production, prices, incomes and ultimately, livelihoods and lives.

\section{Effects of Climate Change on Crop Production: Research Examples}

Climate change impacts on crops yield are different in various areas; some regions will have increased impacts while others it will decrease depending on the latitude of the area and irrigation application. The likely impact of climate change on crop yield can be determined either by experimental data or by crop 
growth simulation models. Akpalu et al. (2008) studied the climate impacts on maize yield in the Limpopo Basin of South Africa and showed that increased temperature and rainfall are responsible for the crop yield and the precipitation is more important for crop yield than the temperature. Krishnan et al. (2007) analysed the impacts of elevated carbon dioxide and temperature on irrigated rice yield in eastern India using ORYZAI and Info Croprice models and the result shows that increased carbon dioxide concentration can increase rice yield, which is concerned with the sterility of rice spikelets at higher temperature, the sowing ting and the selection of genotypes. The United States produces $41 \%$ of the world's corn and $38 \%$ of the world's Soybeans, so any affect US crop yields will have implications for world's food supply. Yields increase in temperature until about $29^{\circ} \mathrm{C}$ for corn, $30^{\circ} \mathrm{C}$ for soybeans and $32^{\circ} \mathrm{C}$ for cotton, but temperature above these levels will become very dangerous (Wolfram and Michael, 2008). The integrated impact of climate change is expected to generally increase crop yields because of the combined effects of carbon dioxide fertilisation, radiation use efficiency and longer growing seasons. Increase in sunflower yields might enable this crop to become competitive with oilseed rape in East Anglia. Smaller increases in yield or possible decreases are expected for light soils in southern England and parts of southeast Scotland that suffer high water stress. Decrease in yields could also be expected for potatoes in Cornwall, oilseed rape in south and southeast England and high quality horticultural crops in Scotland. Increased carbon dioxide concentrations should lead to higher plant productivity. Higher temperatures might, however result in decreased yields, although this would generally be offset by the carbon dioxide fertilisation effect. Increases in grass yields are also generally expected (DERFA, 2014). Climate change causes unpredictable and adverse weather events impact and increasingly affect crop growth, availability of soil water, soil erosion, droughts and dry spells, floods, sea level rises with prevalent infection of diseases and pest infestations (Adejuwon, 2004; Zoellick and Robort, 2009). These environmental problems result to low and inconsistent crop yields, which invariably make farmers more susceptible, especially in African dry zones (Ziervogel et al., 2006). It is projected that crop yield in Africa may fall by $10-20 \%$ by 2050 or even up to $50 \%$ due to climate change (Jones and Thornton, 2002) while food will increase by $70-90 \%$ (De Fraiture et al., 2007). According to Adefolalu (2007); Ikhile (2007), Africa is already being plagued with diverse ecological challenges which have been directly linked with the on-going climate change. Desert encroachment at a very fast rate per year occasioned by fast reduction of water, flura and fauna resources on land (FME, 2004; Obioha, 2008) threaten the Arid and semi-arid zones. Thus, studies on climate change pertaining to rainfall on daily basis are needed most especially for agricultural purposes (Sivakumar, 1992).

\section{Conclusion}

This paper did a review of studies of cases of climate change and its attendant effects on the agricultural environment with emphasis on rainfall, as an important factor. Most studies reviewed indicated that climate change has influenced agricultural production, production stability and incomes in some areas that are already have high levels of food insecurity. Since agriculture has undergo a significant transformation in order to meet related challenges of achieving food security and responding to climate change. Therefore, developing Climate-Smart Agriculture is thus the crucial to achieving future food security and climate change goals. Thus, further studies on climate change as it pertain to rainfall analysis and modeling are crucial for mitigation of its effects on agricultural soil environment and production. There is also the need to educate farmers on the effects of climate change on their farming, crop production and yield. Alternative source of energy to fossil fuel should be also recommended to reduce the global atmospheric gas emissions that contributed to global warming. Regulatory and enforcement agents should ensure that public is appropriately monitored in terms of minimum limit of gas emission globally.

\section{Acknowledgement}

The authors would like to thank UNISA for providing their literature datasets.

\section{Author's Contributions}

Olumuyiwa Idowu Ojo worked in the preparation and development of the manuscript while Masengo Francois Ilunga vetted the manuscript for publication.

\section{Ethics}

Authors declared that there is no ethical issues that may arise after the publication of this manuscript.

\section{References}

Adefolalu, D.O., 1986. Rainfall trends in Nigeria. Theoretical Applied Climatol., 37: 205-219. DOI: $10.1007 /$ BF00867578

Adefolalu, D.O., 2007. Climate change and economic sustainability in Nigeria. Proceedings of the International Conference on Climate Change and Economic Sustainability held at Nnamdi Azikiwe University, Jun. 12-14, Awka, Nigeria.

Adejuwon, S.A., 2004. Impacts of climate variability and climate change on crop yield in Nigeria. Proceedings of the Conference Centre Workshop on Assessment and Adaptation of Impacts of Climate Change (ICC' 2004), Obafemi Awolowo University, Ile-Ife, pp: 271-279. 
Ajayi, A.E., 1998. Agro-statistical analysis of rainfall data for the humid and sub-humid stations of Nigeria unpublished department agricultural engineering, the Federal University of Technology. Akure Ondo-state.

Akonga, A.Z., 2001. The causes and impacts of drought. ANIS Monograph, 3: 1-16.

Akpalu, W., R.M. Hassan and C. Ringler, 2008. Climate variability and maize yield in South Africa: Results from GME and MELE methods. Environ. Produc. Technol. Division IFPRI.

Ali, A.A., 2011. Trends and cycles of rainfall and Temperature for water resources development in Nigeria. PhD Thesis, Federal University of Technology, Akure, Nigeria.

Asafu-Adjay, J., 2008. Climate change and economic development, issues, challenges and opportunities for Africa in the decades ahead. AERC Senior Policy Seminar X. Addis Ababa, Ethiopia.

Asit, M. and S. Neenu, 2012. Impact of climate change on soil biodiversity- a review. Agri. Rev., 33: 283-292.

Brazdil, R., 1992. Fluctuation of atmospheric precipitation in Europe. Geojournal, 27: 275-291.

Bunting, A.H., M.D. Dennet, J. Elston and J.R. Milford, 1976. Rainfall trends in the West African Sahel. Quarterly J. Royal Meteorol. Society, 102: 59-59. DOI: $10.1002 /$ qj.49710243105

Charney, J., W.J. Quirk, S.H. Chow and J. Kornfield, 1977. A comparative Study of the effects of albedo change on drought in semi-arid regions. J. Atmos. Sci., 34: 1366-1385.

Cline, W.R., 2007. Global Warning and Agriculture. Impact estimates by country, centre for global development. Peterson Instit. Int. Econom.

Dai, A., P. Lamb, K.E. Trenberth, M. Hulme and P.D. Jones et al., 2004. The recent Sahel drought is real. Int. J. Climatol., 24: 1323-1331. DOI: $10.1002 /$ joc. 1083

De Fraiture, C., D. Wichelns, J. Rockstrom and E. Kemp-Benedict, 2007. Looking Ahead to 2050: Scenarios of Alternative Investment Approaches. In: Water for Food, Water for Life: A Comprehensive Assessment of Water Management in Agriculture, Molden, D. (Ed.), Earthscan, London, ISBN-10: 1844073963, pp: 91-145.

DERFA, 2014. Impact of Climate change on soil functions. National Soil Resources Institute, Canfield University, Silsoe, Bedfordshire, MK45DT.

EEA, 2008. National emissions reported to the UNFCCC and to the EU greenhouse gas monitoring mechanism v9. Dataset.

EEA-JRC-WHO, 2008. Impacts of Europe's Changing Climate: 2008 Indicator Based Assessment. 1st Edn. Office for Official Publications of the European Communities, Copenhagen, Denmark, ISBN-10: 9291673722, pp: 246.
Ekpoh, I.J., 1991. The Effects of Climatic Variability on Agriculture in Northern Nigeria. PhD Thesis, University of Birmingham, Birmingham B 15 2TT, United Kingdom.

Ekpoh, I.J., 1999. Rainfall and peasant agriculture in Northern Nigeria. Global J. Pure Applied Sci., 5: 123-128.

Ekpoh, I.J., 2007. Climate and society in Northern Nigeria: Rainfall variability and farming. Int. J. Series Tropical Issues, 8: 157-162.

Ekwue, E.I., R.J. Stone and R. Smith, 1997. Statistical analysis of Caribbean rainfall data: Formulating linear models relating dependable rainfall to mean monthly rainfall. West Indian J. Eng., 19: 49-58.

Ezra, J., 2010. Creating climate change awareness on the Nigerian citizens: Challenges for social studies curriculum planners and implementers.

FAO, 2010. Climate smart agriculture: Policies, practices and financing for food security, adaptation and mitigation. Proceedings of the Conference on Agriculture, Food Security and Climate Change, (SCC' 10), Rome, Italy.

Fasheun, T.A., E.O. Udensi and A.B. Ahmed, 1995. A case of climate change in Nigeria: Department of Meteorology, Federal University of Technology. Akure, Nigeria.

Field, C.B., L.D. Mortsch, M. Brklacich, D.L. Forbes and P. Kovacs et al., 2007. North America. In: Climate Change Impacts, Adaptation and Vulnerability. 1st Edn. Cambridge University Press, Cambridge, United Kingdom.

Fisher, A.C., W.H. Michael, J.R. Michael and S. Wolfram, 2007. Potential impacts of climate change on crop yields and land values in U.S. agriculture: Negative, significant and robust.

FME, 2004. Federal ministry of environment. Abuja, Nigeria.

Folland, C.K., T.N. Palmer and D.E. Parker, 1986. Sahel rainfall variability and worldwide sea temperatures, 1901-85. Nature, 320: 602-606. DOI: $10.1038 / 320602 \mathrm{a} 0$

Giannini, A., R. Saravanan and P. Change, 2003. Ocean forcing of Sahel Rainfall on inter-annual to inter-decadal timescales. Science, 302: 1027-1030. DOI: $10.1126 /$ science. 1089357

Hess, K.U., D.B. Dingwell and S.L. Webb, 1995. The influence of excess alkalis on the viscosity of a haplogranitic melt. Am. Mineralogist, 80: 297-304.

Hulme, M., R. Doherty, T. Ngara, M. New and D. Lister, 2001. African climate change: 1900-2100. Clim. Res., 17: 145-168.

Hundecha, Y. and A. Bárdossy, 2005. Trends in daily precipitation and temperature extremes across western Germany in the second half of the 20th century. Int. J. Climatol., 25: 1189-1202. 
Ikhile, C.I., 2007. Impacts of Climate variability and change on the hydrology and water resources of the Benin-Owena River Basin. PhD Thesis University of Benin.

IPCC, 2001. Changes around the Antarctic peninsula. Intergovernmental Panel Climate Change.

IPCC, 2002. Climate Change 2001: Synthesis Report. In: A Contribution of Working Group I, II and III to the Third Assessment Report of the Intergovernmental Panel on Climate Change, Watson, R.T., (Ed.), Cambridge University Press, Cambridge, UK, pp: 239-397.

IPCC, 2007. Climate Change 2007: The Physical Science Basis: Summary for Policymakers. 1st Edn. IPCC Secretariat, Geneva, pp: 21.

Jones, P.G. and P.K. Thornton, 2002. Croppers to livestock keepers: Livelihood transition to 2010 in Africa due to climate change. Global Environmental Change, World Health Organization, Geneva, Switzerland.

Klein-Tank, A.M.G. and G.P. Können, 2003. Trends in indices of daily temperature and precipitation extremes in Europe, 1946-1999. J. Clim., 16: 3665-3680.

Krishnan, P, D.K. Swain and B.C. Bhaskar, 2007. Impact of elevated $\mathrm{CO} 2$ and temperature on rice yield and methods of adaptation as evaluated by crop simulation studies. Agric. Ecosyst. Environ., 122: $233-42$.

L'Hôte, Y., G. Mahé, B. Somé and J.P. Triboulet, 2002. Analysis of a Sahelian index from 1896 to 2000; the drought continues. Hydrol. Sci. J., 47: 563-572.

Le Barbe, L. and T. Lebel, 1997. Rainfall climatology of the HAPEX-Sahel region during the years 1950-1990. J. Hydrol., 188-189: 43-73. DOI: 10.1016/S0022-1694(96)03154-X

Mills, E., 2007. From risk to opportunity: Insurer's responses to climate change. Cares Report.

Moberg, A. and P.D. Jones, 2005. Trends in indices for extremes in daily temperature and precipitation in central and western Europe, 1901 - 1999. Int. J. Climatol., 25: 1149-1171. DOI: 10.1002/joc.1163

Moberg, A., P.D. Jones, D. Lister, A. Walther and M. Brunet et al., 2006. Indices for daily temperature and precipitation extremes in Europe analyzed for the period 1901-2000. J. Geophys Res-Atmos, 111: 1-25. DOI: $10.1029 / 2006 d j 007103$

Morele, A., S. Ladet, N. Coque and A. Gibon, 2003. Agricultural land-use change and its drivers in mountain landscapes: A case study in the Pyrenees. Agric., Ecosyst. Environ., 114: 296-310. DOI: $10.1016 /$ j.agee.2005.11.017

Nicholson, S.E., D. Klotter and A.K. Dezfuli, 2012. Spatial reconstruction of semi-quantitative precipitation fields over Africa during the nineteenth century from documentary evidence and gauge data. Quat Res., 78: 13-23.
Nicholson, S.E. and C.J. Tucker, 1998. Desertification, drought and surface vegetation: An example from the West African Sahel. Bull. Am. Meteorol. Society, 79: 815-829.

Nicholson, S.E., 1993. An overview of African rainfall fluctuation of the last decade. J. Clim., 6: 1463-1466.

Obioha, 2008. Climate change, population drift and violent conflict over land resources in North Eastern Nigeria. J. Human Ecol., 23; 311-324.

Odingo, R.S., 2008. Climate change and economic development, issues, challenges and opportunities for Africa in the decades ahead. University of Nairobi.

Ofori-Boateng, K., 2012. Climate change and cocoa production in West Africa. PhD Thesis. University of Ibadan.

Opoku-Ankomah, Y. and B.A. Amisigo, 1998. Rainfall and runoff variability in the southwestern river system of Ghana: Water resources variability in Africa during the XXth century--Variabilite des resources en eau en Afrique au XXeme siècle. IAHS-AISH Publication. 252: 307-307.

Osborn, T.J., M. Hulme, P.D. Jones and T.A. Basnett, 2000. Observed trends in the daily intensity of United Kingdom precipitation. Int. J. Climatol., 20: 347-364.

Parry, M.L., C. Rosenzweig, A. Iglesias, M. Livermore and G. Fisher, 2004. Effects of climate change on global food production under SRES emissions and socio-economic scenarios. Glob Environ. Change 14: 54-67.

Reuben, S., 2012. Climate Smart Agriculture Source Book. 1st Edn. Food and Agriculture Organisation of United Nations, Rome, Italy.

Rubas, D.J., H.S.J. Hill and J.W. Mjelde, 2006. Economics and climate applications: Exploring the frontier. Climate Res., 33: 43-54.

Salami, A., 2010. Climate change mitigation and adaptation options: The Nigeria experience.

Schonwiese, C.D., J. Rapp, T. Fuchs and M. Denhard, 1994. Observed climate trends in Europe 18911990. Meteorologische Zeitschrift, 3: 22-28.

Schonwiese CD, Rapp J. 1997. Climate Trend Atlas of Europe Based on Observations, 1891-1990. Kluwer Academic Publishers: Dordrecht/Boston, MA/London.

Sivakumar, M.V.K., 1992. Climate Change and implications for agriculture in Niger. Climate Change. 20: 297-312.

Stern, N., 2006. Stern Review on the Economics of Climate Change. 1st Edn. HM Treasury, London.

Tarhule, A. and M. Woo 1998. Changes in rainfall characteristics of northern Nigeria. Int. J. Climatol., 18: 1261-1271.

Timothy, J.F., T.W. Colin, D. Austin and T. McGuire, 2002. Processes of adaptation to climate variability: A case study from the US Southwest. Clim Res., 21: 299-310. 
Tosic, I. and M. Unkasevic, 2005. Analysis of precipitation series for Belgrade. Thor. Applied Climatol. 80: 67- 77.

Ward, M.N., C.K. Folland, K. Maskell, A.W. Colman and D.P. Rowell et al., 1993. Experimental seasonal forecasting of tropical rainfall at the UK meteorological office. Prediction Interannual Clim. Variations. NATO ASI Series, 6: 197-216.

Winstanley, E.E., 2003. Complementarily between densification and climate change conventions responses to unpredictable rainfall patterns in Nigeria, Dry Belt NEST Forum No. 19: 7-8.

Wolfram and Michael, 2008. Estimating the impact of climate change on crop yields: The importance of non-linear temperature effects. Columbia University, New York.
WTO-UNEP, 2009. Trade and Climate Change. Geneva, Switzerland. WTO UNEP,

Ziervogel, G., A. Nyong, B. Osman, C. Conde and S. Cortes et al., 2006. Climate variability and change: Implications for household food security. Proceedings of the Assessment of Impacts and Adaptations to Climate Change (ACC' 06), Washington DC, USA, pp: 678-691.

Zoellick, S. and B.A. Robort, 2009. Climate Smart Future: The National Newspaper. 1st Edn. Vintage Press Limited, Lagos, Nigeria, pp: 18.

Zolina, O., C. Simmer, A. Kapala and S. Gulev, 2005. On the robustness of the estimates of centennialscale variability in heavy precipitation from station data over Europe. Geophys. Res. Lett. DOI: $10.1029 / 2005$ GL023231 